\title{
Removing Political Barriers to Engagement: The Advisory Roles of Political Scientists in Albania
}

Nevila Xhindi and Blerjana Bino

\subsection{INTRODUCTION}

There is no systematic research into the key features of the Policy Advisory System in Albania that shows and discusses analytical capacities at local and central governmental levels. The majority of existing reports explore broad participation in decision-making processes and the interaction of civil society and government. Furthermore, most studies concern disciplines such as economics, finance and law rather than political science and its impact on policy. Some more recent studies have focused on public administration, but with no particular focus on political science per se, and its impact on policy.

This chapter aims to bridge this gap by analyzing Albania's policy advisory system, focusing on the advisory roles that political scientists see for themselves and engage in. The chapter starts by outlining the discipline of

N. Xhindi

Mediterranean University of Albania, Tirana, Albania

B. Bino $(\bowtie)$

Centre of Science and Innovation for Development, Tirana, Albania

(C) The Author(s) 2022

67

M. Brans, A. Timmermans (eds.), The Advisory Roles of Political

Scientists in Europe, https://doi.org/10.1007/978-3-030-86005-9_4 
political science in Albania, which is relatively new having developed for the best part since the turn of the century. It then analyzes the process of policy development and how different factors may hinder demand for policy advice in that country. The chapter's final section considers the role of political scientists within the national context. Political barriers limit the role of political scientists in the policy process. Political scientists themselves are not normally committed to engaging in policy advisory activities. In the Albanian system, they have little incentive for such engagement outside of their own universities.

\subsection{Political Science as an Emerging Discipline in Albania’s Academia}

After World War II, Albania entered what was to be a 45 -year-long period of communist dictatorship, considered one of the harshest of its kind in terms of limitations on political freedom and human rights. After breaking strategic alliances with Yugoslavia first, then with the Soviet Union, and lastly with China, in the late 1970s the country became extremely isolated. This period significantly impacted the country's political and economic standards, making it the poorest and least democratic country in Europe by 2011 , when communism collapsed. The regime's legacies, in terms of its impact on political culture, are still present. This is also reflected in the political approach leaders have within their own party and how they make decisions.

During communism, social sciences became a crucial instrument with which to thoroughly politicize the education of young Albanians, with their first priority being declared as that of defending Marxist-Leninist principles (Bowers, 1989, p. 445). The propagation of communist ideology and the political indoctrination of youth constituted the fundamental purpose of higher education as well. Against this backdrop, in 1965 the Faculty of Political and Juridical Sciences was established within the State University of Tirana. Its two central departments were Political Science and Law. In 1967, a Department of Journalism was also established in this Faculty. In the 1970s, philosophy replaced political science. During the communist regime, the social sciences, and particularly political science, public policy and public administration, had been "eradicated by 'scientific socialism' and Marxism-Leninism” (Eisfeld, 2012, p. 85). It was only after the 1990s that contemporary political science was re-introduced into 
Albanian higher education. In 1991, the aforesaid Faculty was split and a separate Faculty of Law established, offering law courses only, while journalism was incorporated into the Faculty of Philology and History.

Tirana's Faculty of Social Sciences was established in 1991, in the aftermath of the transition from communism to a democratic political system. Initially, the faculty was labeled the Faculty of Social Work, and it operated in conjunction with Gran Valley University in the USA. In 1992, it became the Faculty of Social Sciences and comprised three departments: Social Work, Psychology-Pedagogy, and Philosophy-Sociology. The Faculty only began to offer a study program in political science in 2000 , and the Department of Political Science, Philosophy and Sociology was established some years later, in 2009. Currently, the Department of Political Science is the country's largest political science department. The University of New York Tirana (UNYT) was founded in 2002 as part of the New York College (NYC) Network of Educational Institutions, and was the first private University in Albania to introduce a new Department of Political Science. There are now five private universities in the country offering political science programs. Currently, there is one joint master's degree program in political science on offer-Integration and Governance-run jointly by the University of Salzburg, the University of Ljubljana, and universities in the 6 Western Balkan countries, including two universities from Albania as part of the consortium: the University of Tirana and the European University of Tirana.

With the fall of the communist regime, changes were also witnessed in the academic field. The international community played a crucial role in aligning higher education reforms with the European Education Area. The United States played an active role in Albania during the 1990s by providing pedagogical support for modernizing higher education and institutionalizing political science as a discipline within the University of Tirana (Eisfeld, 2012, p. 86). The European approach to political science was introduced mainly through the EU's curricula development programs, such as Tempus (Trans-European Mobility Programme for University Studies) and more recently Erasmus+ program. Another catalyst in the development of political science in Albania has been the Open Society Foundations of George Soros, particularly in the teaching and training of academic staff. In Albania's case, the Open Society Foundation has sponsored research in political science and provided foreign scholarships to the best students. Furthermore, private research institutes, such as 
think tanks, were established with the support of foreign donors. These initiatives all increased the demand for political scientists.

The original academic background of teachers of political science was mainly law and philosophy. When the new political science program was introduced in 2000, most professors and lecturers were trained in philosophy, while some had a background in sociology, law, journalism, or communication science. Some professors trained in political science came from abroad, or were Albanian scholars who did a master or PhD in another country. There was a certain tension between the 'old generation' of philosophers now engaging in political science, and the 'new generation' of political scientists, in terms of how a new political science curriculum should be developed, and what its core elements and objectives should be. From 2007 onward, a new generation of political scientists who had graduated in Albania or abroad started to establish chairs and build departments in political science in Albania's private universities. The University of Tirana's Faculty of Social Sciences offered a PhD in Political Science in 2011.

The scholarly community in Albania divulges its work via three main academic journals: the Albanian Journal of Politics (established in 2005), and Polis (2006), both peer-reviewed journals that publish in English; and Politics and Society (2000) which publishes in Albanian. Albania also has an Association of Political Science, which was established in 2000, but has yet to join the International Association of Political Science (IPSA). According to the Ministry of Education, Sports and Youth, about $50 \%$ of university-based researchers in the country work in the fields of the social sciences and humanities, economics and business studies. Some 15\% of staff operate in economics, finance, and business, compared with $3 \%$ in political science and international relations. About $70 \%$ of all scholars have tenure.

\subsection{The Policy Advisory System}

The policy cycle including the choice of processes and tools, while the presence of, and competition among, actors and stakeholders constitutes a complex area of research and practice. Firstly, Albania's cycle of policy development is framed by a free-market economy and a representative democracy that have faced a great many challenges and undergone a series of significant transformations. Secondly, democratization processes and European integration ambitions have had a profound impact on policy 
design and decision making within the country (Xheneti \& Kitching, 2011 , p. 1019). Furthermore, policy transfer is an integral part of the democratization processes that transform ideas into policy, in which international actors such as the World Bank, the International Monetary Fund and the European Commission, play a key role. What is more, a political landscape characterized by adversity, power struggles, and polarization has had profound implications for all aspects of policy development in the country.

Thus, an increasingly varied range of actors is involved in the policy cycle in Albania through interlinked processes both within the country and between the domestic area and international arenas. These interconnections are evident in legislative activities, executive policymaking and local policymaking. The judiciary also plays a key role in ensuring the compatibility of legislation with Albania's Constitution and with international treaties. Other actors from civil society include interest groups, trade unions, and advocacy groups on all kinds of issues, the media, and academia. In the country's democratic system, political parties have achieved representation among these actors.

Albania's main national decision-making system for the drafting of policies and strategies is the Integrated Planning System (IPS). The IPS provides a comprehensive planning framework whereby all government policies and financial planning function in a coherent, efficient, integrated manner. Moreover, the IPS is supported by the Integrated Policy Management Groups (IPMGs) to "develop, implement and monitor sectoral reforms in Albania" (MIAP \& DAP, 2015). The IPMGs serve as the main forum for policy dialog between government representatives, partners for development and integration, and civil society within the country. Albania has only recently been building the systems and culture required for evidence-informed policymaking, which in turn requires high-quality knowledge production, knowledge intermediaries, and a regulatory framework that creates incentives for doing (policy) research as well as using research results in policy decisions (Pellini, 2018).

External political advisors, who are only allowed to advise the Prime Minister, also play a strategic part in public policy development. Although they are not in charge of actual decision making, they participate in the process, they possess information, they have networks, they can request further information and communicate with different institutions; consequently, they may be deemed to be influential as well. Examples include Tony Blair's consulting company, in 2013 and 2017, the Harvard Kennedy 
School of Governance, and a Swedish team of political consultants. These external political advisors to the Prime Minister, who have provided political policy advice on key reforms, are of an international character, being either foreigners or Albanian political scientists living abroad. This would seem to indicate that policy makers generally place more trust in advice from foreign sources than that provided by advisers operating in Albania.

\subsection{Evidence-Based Policy Making in Albania}

Since 2014, Albania has had an improved legal framework governing the policy advisory system, with a law on the right to information-Law No. $119 / 2014$ - and a law on the public consultation of policy and legislative acts-Law No. 146/2014. This legal framework provides formal mechanisms and spaces for various actors to participate in policy making, with the primary goal of increasing the efficiency, transparency, and public accountability of state institutions. However, the practical implementation of these changes to policy-making procedures appears to be limited still (Dauti \& Bejko, 2015). Despite recent achievements, several important challenges remain, such as the risk of a fragmentation of the process, a lack of transparency, the greater need for genuine consultation with stakeholders, and the need for evidence-based decision-making processes (Dauti \& Bejko, 2015). The policy advisory system lacks specific mechanisms, processes and incentives for evidence-based policy making, with the attention focused more on consultation with various interest groups. The political agenda prevails even when policy makers are presented with evidence (Bejko \& Dauti, 2019). Although there is increased interest in evidencebased policy making, in practice there is a limited degree of uptake of research into the policy development process.

A recent study of think tanks and evidence-based policy making in Albania (Xhindi \& Włoch, 2018) found that Albania’s genuine think tanks are limited in number. The think tank sector has grown since 2010. There are some NGOs that have shifted from community mobilization and advocacy organizations to a more think-tank profile. The Albanian think tanks are willing to cooperate with the government in the field of policy advice, but the demand, funding and access points for doing so are limited. The same study reports that in the Albanian context, while think tanks may contribute to the growth of civil society and democracy, on the other hand they are at a constant risk of being hijacked by the political agendas of interest groups and political parties. Cooperating with think 
tanks stimulates the development of young social science researchers. According to Xhindi and Włoch (2018), many staff in their organizations are current or former academics. Most importantly, think tanks offer young researchers access to their "social capital", that is, networks enabling future cooperation, crucial for building their professional portfolios and accessing new opportunities.

The power-knowledge nexus in Albania is deficient on the demand side (Xhindi \& Włoch, 2018). In a purely instrumental way, the government uses NGOs and think tanks to uphold the façade of the participatory decision-making process. Even though civil society organizations take part in the consultation process, they are rarely given adequate time to offer scholarly expertise based on reliable studies. Not only is think tank expertise very rarely utilized by the authorities, but it also fails to attract the interest of the business sector in Albania. All in all, this means that for the time being, there are virtually no other substitutes for foreign donor financial support and foreign grants will have to act as a life-line for Albania's think tanks and for the political scientists they appoint as experts, for the foreseeable future.

Another study (Bino et al., 2020) argues that the appropriate steps required for tangible cooperation to be established between academia, civil society and public institutions, are not being taken. Governmental institutions seem to lack those mechanisms that operationalize policies into practices, and those processes that permit the soliciting of advice. The partnership between civil society and public institutions must be understood as uninterrupted continuous circular process of assessment, planning, execution, monitoring, evaluation, and feedback. ${ }^{1}$ For instance, although the law on public consultation is clear in terms of its significant expectations, institutions have not developed specific procedures to ensure any significant applicability. Part of the reason why these practices are not in place is that institutions have not developed binding procedures for the structures for ensuring the effective implementation of the law on public consultation, its outcomes, and implications for policy decisions.

\footnotetext{
${ }^{1}$ Interview with civil society representative 1 .
} 


\subsection{Political Scientists: Types of Advisory Role, Activities ANd Viewpoints}

Based on the operational definition of the ideal types of political scientists outlined in Chaps. 2 and 3 of this book, most political scientists in Albania (44\%) can be classified as pure academics who do not engage in any advisory activity. A smaller group (28\%) of political scientists are experts who offer advice on a variable basis, often formally and upon request. They usually provide advice based on policy-oriented and applied research. Just behind the experts lies the group of opinionating scholars (23\%): these are political scientists who provide more informal, opinionated advice often combining normative positions with factual knowledge. Very few political scientists can be classified as public intellectuals-only 5\% (or just two out of the 43 political scientists included in the Albanian population of respondents) (Table 4.1).

Compared to the average for all countries, female political scientists take a larger share in Albania, with $44 \%$ against 56\% male colleagues. As Fig. 4.1 shows, most female political scientists in Albania are pure academics $(53 \%)$, followed by experts (32\%) and opinion makers (16\%).

There are no women in the public intellectual category; however, in the category of experts, there are more women than there are men. While the largest group of both male and female political scientists is that of the pure academics, this predominance is more marked in the case of female scholars. Compared to their female colleagues, male political scientists are clearly more active as opinion makers. To sum up this analysis of gender

Table 4.1 Types of advisory role-Albania

\begin{tabular}{|c|c|c|c|c|}
\hline Advisory role & $\begin{array}{l}\text { Frequency of } \\
\text { advice }\end{array}$ & Type of knowledge & $\begin{array}{l}\text { Frequency } \\
(N)\end{array}$ & $\begin{array}{c}\text { Frequency } \\
(\%)\end{array}$ \\
\hline Pure academic & Never & $\begin{array}{l}\text { Only pure scientific } \\
\text { knowledge, episteme }\end{array}$ & 19 & $44 \%$ \\
\hline Expert & Variable & $\begin{array}{l}\text { Scientific or applied (techne, } \\
\text { what works) }\end{array}$ & 12 & $28 \%$ \\
\hline $\begin{array}{l}\text { Opinionating } \\
\text { scholar }\end{array}$ & Variable & $\begin{array}{l}\text { Opinionated normative science } \\
\text { phronesis, what must be done }\end{array}$ & 10 & $23 \%$ \\
\hline \multirow[t]{2}{*}{$\begin{array}{l}\text { Public } \\
\text { intellectual }\end{array}$} & Ongoing & $\begin{array}{l}\text { Episteme, techne and } \\
\text { phronesis }\end{array}$ & 2 & $5 \%$ \\
\hline & & Total & 43 & $100.0 \%$ \\
\hline
\end{tabular}

Source: ProSEPS survey data 


\section{PUBLIC INTELLECTUAL}

OPINIONING SCHOLAR

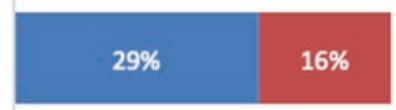

EXPERT

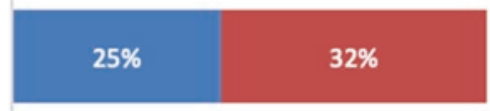

PURE ACADEMIC

Fig. 4.1 Gender of advisory role types-Albania. (Source: ProSEPS survey data)

differences among Albania's political scientists: male scholars appear more active in the public sphere (opinionating and public intellectual roles), while female scholars are either inactive or operate as experts, often in arenas that are less publicly visible.

The vast majority of political scientists in universities, both public and private, are employed on permanent contracts (tenured positions). Seven universities in Albania have a political science department serving as a basis for full-time political scientists. Two of them are public universities (in Tirana and Durres), while five are private institutions all located in Tirana. Advisory activities are conducted on the basis of temporary service contracts, primarily in Tirana. All 43 of the political scientists comprising the population of respondents are under 50 years of age, which is not surprising considering the relatively new status of political science as an academic discipline in Albania.

It follows from the distribution of role types that Albanian political scientists display a relatively low degree of engagement with policymakers. Primarily, political scientists engage with societal actors such as think tanks and NGOs to provide their expertise in policy-oriented and applied 
research. This provision of advice is based on service contracts, usually within the framework of donor-funded projects. In Albania, political scientists provide advice to policymakers mainly through the advocacy and lobbying performed by societal actors and facilitated by international organizations. In this sense, the primary beneficiaries, that is, the actors receiving the advice, are civil society organizations, NGOs, think tanks and international organizations. Legislative and executive politicians are less frequently the direct recipients of advice, while the least targeted groups are political parties and interest groups operating in the private sector, as shown in Table 4.2.

Political scientists occasionally provide informal political advice to publicly-elected officials such as parliament members, local government council members, or mayors, although this is done on an ad hoc basis through personal connections and networks. Some political scientists

Table 4.2 Principal recipients of advice-Albania

\section{Recipients of advice Experiences of political scientists}

\section{Political actors}

Executive politicians

Legislative politicians

Political parties

Bureaucratic actors

Civil servants

Advisory bodies

Societal actors

Think tanks

Interest groups

(private sector)

Civil society

organizations

International actors

International

organizations
Rarely, or through advocacy and lobbying by CSOs and INGOs

Mainly through advocacy and lobbying by CSOs and INGOs, or through the attendance of open hearings of parliamentary committees

Mostly informal and on an ad hoc basis

Very rarely with very limited requests for advice solicited and minimal access points

Very often through consultancy and with donor-funded projects

Very rarely

Very often through consultancy and with donor-funded projects

Very often through consultancy and open calls for engagement

\section{Source: ProSEPS survey data}

Notes: Question: "How often, on average, during the last three years, have you engaged in any of the following advisory activities with policy actors (policymakers, ministry officials, interest groups, political parties, etc.)?" including only those respondents who indicated 'at least once per year' 'once per month' or 'once per week' 
utilize a formal mode of engagement with policy advice, in regard to electoral reform, the election process, and the party system, and on matters of transparency and accountability, policy reform, public administration reform and European integration. These areas have been a key priority for the Albanian government over the past decade, in view of its position on the EU. Albania's international donors have pushed for engagement and the provision of evidence in policymaking, thus facilitating access points for the political scientist as advisors. Albania's Parliament recently engaged in activities designed to bolster its links to academia and societal actors by improving the existing consultancy mechanisms. Since 2020, the Swiss Agency for Development and Cooperation has been funding a project for the creation of a Parliamentary Research Unit. This may in turn permit greater interaction between political scientists and political actors.

Albanian political scientists utilize various channels to provide policy advice and consultancy services, including publications, research reports, policy papers, and also media articles such as editorials. Blogs and social media have been less frequently used in the past, and have only recently gained popularity, and mostly among young political scientists. The frequency of policy advice provision varies. For instance, publications and research reports are usually produced once a year, while policy papers tend to be published twice a year. Media articles and other forms of communication through online social media are more frequent. Training courses for policymakers are a rarer form of service provision offered by political scientists, and they are usually provided with the help of international organizations and in projects funded by donors.

The most popular type of advisory activity is policy analysis and consultancy, generally through societal actors such as think tanks, NGOs, and international organizations; this is followed by the provision of data and facts. Table 4.3 summarizes the findings regarding the types of advice provided. Furthermore, political scientists reported that they engage less in policy evaluation, forecasts and polls, while both opinionating scholars and public intellectuals confirm that they offer value-judgments and normative arguments, albeit to differing degrees. Only one small group of political scientists offers various forms of advice very frequently; this group comprises political scientists employed by the country's universities and those who are working part-time or on a contract basis in the civil society sector.

There appear to be high expectations for Albania's political scientists to become engaged in policy making, and particularly in public debate. 
Table 4.3 Types of advice-Albania

\begin{tabular}{ll}
\hline Type of advice & Experiences of political scientists \\
\hline Data and facts & $\begin{array}{l}\text { Experts; Once a year; Consultancy services for societal } \\
\text { actors; Increasing interest from political actors }\end{array}$ \\
Experts; More than once a year; Consultancy services for \\
societal actors and political actors
\end{tabular}

Source: ProSEPS survey data

Notes: Question: "How often, on average, during the last three years, have you engaged in any of the following advisory activities with policy actors (policymakers, ministry officials, interest groups, political parties, etc.)?" including only those respondents who indicated 'at least once per year' 'once per month' or 'once per week'

Universities themselves are reforming their performance indicators by focusing on the impact on, and links with policymakers, civil society, the media, and the private sector. National higher education and research reforms since 2016 have acknowledged the importance of applied and policy-oriented research and its impact on policymaking. Promotion systems and academic career path procedures now recognize and reward impact-related research and the engagement of academics in policy advice, albeit not necessarily financially. Most of the surveyed political scientists consider engagement to be their professional responsibility to the public, and most of them think that contributing to society is very important. Still, in Albania, moving from a role as a pure academic to become an expert, opinionating scholar or public intellectual is difficult and scholars doing this encounter many hazards.

\subsection{Discussion}

The findings show that political scientists find it very challenging to engage with policymakers and act effectively from the supply side of knowledge production. Individual researchers motivation to engage with policy 
research and policymakers is determined by various factors (Shaxson, 2017). Through six in-depth interviews with political scientists for the purpose of this chapter, we found that political scientists who have had previous personal connections to, and experience of, policymakers and practitioners either at central or local level, tend to engage more in policyoriented research and find it easier to do so. As one senior researcher pointed out, "My experience serving as a Member of Parliament and advisor Prime Minister Office and my work with the Bank of Albania, has helped me to understand the underlying logic of how policy and decisionmaking work and it has helped my research too". ${ }^{2}$

Second, political scientists vary in their desire to engage with the public and in the rate of engagement. Some political scientists are not interested in policy-oriented or applicable research, and prefer to do work on fundamentally scientific topics-they see themselves as the pure academic type. Third, political scientists also have other priorities that do not necessarily coincide with those of agenda/policy-driven research. One researcher emphasized, "My research area is particular and mainly theory-driven, it requires a lot of data collection and thus funding, before I can produce any meaningful results and my priority is the quality of the research and not its potential link to certain policy action". ${ }^{3}$ Fourth, the resources and personal skills needed to engage with policymakers are developed at different levels among political scientists. As such, the common denominator of all the in-depth interviews with researchers regarding their engagement in policy research was the "lack of availability of funds and the adequate competences to carry out policy-oriented research with meaningful and applicable results for policymakers". ${ }^{4}$

Another challenging aspect of the science-to-policy dialectic is the disconnection between supply and demand, meaning that while demand is changing rapidly in policy-making institutions and arenas, the supply side is moving more slowly since funding for solicited knowledge production for policymaking purposes is scarce. Another challenging aspect is the mutual distrust that characterizes the relationship between policymakers and researchers, where reputations and levels of legitimacy are perceived very differently. Researchers do not have much trust in policymakers, whose actions are perceived as driven by political aims, EU rules or vested

\footnotetext{
${ }^{2}$ In-depth interview with researcher in political science, September 2019.

${ }^{3}$ In-depth interview with researcher in political science, September 2019.

${ }^{4}$ In-depth interview with researcher in political science, September 2019.
} 
economic interests. On the other hand, policymakers frequently cast doubt on the quality of research and the reliability of social science researchers' data and facts in Albania. Such mutual distrust is also fueled by Albania's unclear policy processes and the nation's issues linked to corruption and the lack of transparency. This mutual distrust also reflects the low quality of research produced in Albania, and the willingness of policy makers to bridge this communication and trust gap.

The analysis of the in-depth interviews shows that researchers consider certain fundamental factors to be key to bridging the gap between researchers and policymakers and to providing incentives for engagement in policy-oriented research. Those incentives suggested are not only of a financial nature, but also include policy-oriented research as part of academics' official credentials and career path development, or that it should be offset against their teaching requirements. In addition to researchers' willingness to engage with knowledge and advice in the policy process, another key factor is the support provided by institutions for those researchers who engage with the policy domain. Some researchers have suggested that universities develop specific forms of cooperation with the policy and private sectors.

The political environment in Albania shapes the attitudes of government officials toward evidence, and even when scientific evidence is presented, they tend to preserve their political agenda (Bejko \& Dauti, 2019). As a result of the often heavily contested political goals and policy options in policy-making arenas, multiple political crises and deadlocks, the window for scientific policy advice is quite narrow. Paradoxically, while political and social changes in the country over the past two decades have given rise to an increase in the number of political scientists working in academia, this has not been accompanied by a more prominent role in the policy advisory system. This has also led many political science graduates to look for employment in areas unrelated to their studies, as there is limited demand for political scientists.

\subsection{Conclusion}

This chapter provides the first systematic account of the policy-advisory role of Albanian political scientists, which for various reasons they often decide not to undertake. It offers an empirical insight into a thus far rather neglected subject, while at the same time it hopes to contribute to the debate among Albanian political scientists regarding the relevance of their 
discipline and its role in contemporary political and social developments. In general, Albanian political scientists do engage in policy advisory activities, but not in a structured, well-organized way. Such activities tend to be informal and based on a network of connections. However, political scientists engage in policy advice more with societal actors than directly with legislative or executive institutions and officials. The role-type of the largest group of Albanian political scientists is that of the pure academic, followed by the expert, the opinion maker, and the public intellectual. Almost half $(44 \%-19$ out of 43$)$ of all respondents in the survey conducted for this project have remained in the university area, where they primarily teach and focus on the research publications necessary for the development of their academic careers, without engaging in external advisory activities. Nonetheless, an emerging group of political scientists now see themselves more as experts engaged in policy advisory roles with societal actors such as think tanks, NGOs, and international organizations. These political scientists in expert roles do not provide advice very often. More frequent are the activities of opinionating scholars. They "sit" closer to the political debates in the country.

The most common means of advice provision are workshops, conferences, and face-to-face contact with actors or organizations, particularly in parliamentary committee hearings or in consultancy services offered to think tanks and international organizations. The most popular channels for the provision of policy advice are publications, articles, research reports, and policy papers. However, these channels are typically rooted in the peer-to-peer communication mode of academic tradition. Communicating political scientific knowledge and findings in ways that are suitable for different audiences with different capacities to absorb the advice, remains limited. There is a smaller group of political scientists categorized as opinion makers who utilize mass media: traditional media articles, appearances in TV debates or shows, and more recently, opinion pieces and blogs written for online media. Despite these activities, the advisory work done by political scientists in Albania is still very much rooted in academic tradition.

Albanian political scientists generally agree with the statement that political scientists should engage in public debate, since this is part of their role as social scientists. However, few of them do so in reality, and they tend to stick to the traditional modes of academic knowledge exchange. Future research may include the demand side of policy advice, in order to better understand the role of political scientists and provide clues to their future engagement. 


\section{REFERENCES}

Bejko, E., \& Dauti, M. (2019). The politics of evidence-based policymaking in Albania: Implications for human rights advocates. Journal of Human Rights and Social Work, 4, 83-90.

Bino, B., Qirjazi, R., \& Xhafa, A. (2020). CSO participation in decision making in Albania. IDM. https://idmalbania.org/report-cso-participation-indecision-making-in-albania/

Bowers, S. R. (1989). Stalinism in Albania: Domestic affairs under Enver Hoxha. East European Quarterly, XXII(4), 441-456.

Dauti, M., \& Bejko, E. (2015). Use of scientific evidence in designing social protection policies in Albania (National Policy Dialogue in Albania). Institute for Democracy and Mediation. http://idmalbania.org/wp-content/ uploads /2014/10/RRPP_Policy-Document-nol-Albania.pdf

Eisfeld, R. (2012). Radical approaches to political science: Roads less traveled. Barbara Budrich Publishers.

Law No. 119/2014. On the right to information.

Law No.146/2014. For notification and public consultation.

MIAP and DAP. (2015). Crosscutting public administration reform strategy 2015-2020. Ministry of Innovation and Public Administration. http://dap. gov.al/images/DokumentaStrategjik/PAR_Strategy_2015-2020_English.pdf

Interview with Arnaldo Pellini. Overseas Development Institute. (2018). Retrieved January 4, 2021, from https://www.odi.org/blogs/10639-building-statecapability-evidence-informed-policy-making-albania-conversation-abi-dodbiba

Shaxson, L. (2017). SUPPORTING IMPACT | The impact initiative. Retrieved August 5, 2017, from https://www.theimpactinitiative.net/impact-lab/collection/supporting-impact

Xheneti, M., \& Kitching, J. (2011). From Discourse to Implementation: Enterprise Policy Development in Postcommunist Albania. Environment and Planning C: Government and Policy, 29(6), 1018-1036.

Xhindi, N., \& Włoch, R. (2018). Think tanks' role in policy development in Albania. PERFORM. 
Open Access This chapter is licensed under the terms of the Creative Commons Attribution 4.0 International License (http://creativecommons.org/licenses/ by $/ 4.0 /$ ), which permits use, sharing, adaptation, distribution and reproduction in any medium or format, as long as you give appropriate credit to the original author(s) and the source, provide a link to the Creative Commons licence and indicate if changes were made.

The images or other third party material in this chapter are included in the chapter's Creative Commons licence, unless indicated otherwise in a credit line to the material. If material is not included in the chapter's Creative Commons licence and your intended use is not permitted by statutory regulation or exceeds the permitted use, you will need to obtain permission directly from the copyright holder. 